\title{
"Você liga demais para os sentimentos" "Bem-estar animal", repressão da afetividade, sofrimento dos pecuaristas
}

\author{
Jocelyne Porcher, dra. \\ Laboratoire de Psychologie du Travail et de l'Action \\ Conservatoire National des Arts et Métiers \\ 41, rue Gay-Lussac \\ 75005 Paris França \\ E-mail: jocelyne.porcher@cnam.br
}

\begin{abstract}
Resumo
A legitimidade moral e econômica dos sistemas industriais e intensivos de produção animal implantados na França a partir da década de 1960 é hoje contestada, por várias razões. As críticas são principalmente formalizadas na questão do "bem-estar animal". Mas os pecuaristas também têm sido afetados pela violência dos sistemas e por uma organização do trabalho reificada que os obriga a reprimir a parte afetiva e relacional de seu trabalho. 0 sofrimento gerado por esses sistemas questiona o próprio sentido das atividades da pecuária e a perenidade do laço social construído por dez mil anos de história compartilhada com os animais domésticos.
\end{abstract}

Palavras-chave

Produção de animais, psicodinâmica do trabalho, organização do trabalho, laço

\section{"You care too much for feelings" "Animal well-being", repression of affectivity, cattle raisers' distress}

\begin{abstract}
The moral and economic legitimacy of the industrialized animal production intensive systems implemented in France from the 1960s is now contested for different reasons. The criticisms are mainly formalized on the "animal wellbeing" issue. However, the cattle raisers have also been affected by the violence of the systems and by a reified work organization which forces them to repress the affective and relational side of their work. The suffering generated by these systems challenges the very meaning of cattle raising activities and the endurance of the social bond constructed by ten thousand years of history shared with domestic animals.
\end{abstract}




\section{INTRODUĈ̣̃O}

O desenvolvimento dos sistemas industriais e intensivos, principalmente desde a década de 1960 na França, levou a profundas transformações das representações do animal de pecuária e do ofício de pecuarista. Entre criação de animais e "produção animal", o trabalho da pecuária foi quase reduzido exclusivamente a sua racionalidade econômica. Os conteúdos relacionais do ofício, majoritariamente considerados como "improdutivos" pelo gerenciamento técnicoeconômico dos pecuaristas, foram relegados a meras velharias tão obsoletas quanto inadequadas no contexto da guerra econômica na qual estariam engajadas as cadeias de produção animal e os pecuaristas.

Quando os pecuaristas conseguem equilibrar os termos de suas trocas com os animais, o ofício de pecuarista integra enormes potencialidades de prazer no trabalho e de felicidade. Em situações de crise, e mais amplamente no quadro da intensificação e da industrialização do trabalho, estarão os pecuaristas em condição de trabalhar com seus animais como acham que deveriam? Não estará a organização do trabalho produzindo afetos negativos (culpa, vergonha, remorsos, sentimentos de traição, de incompetência, de insuficiência...) que constituem uma carga mental dolorosa para se carregar?

Após recapitular brevemente a implantação da "produção animal" na França, mostrarei sucintamente que a temática científica do "bem-estar animal" se construiu, no contexto de uma intensificação constante do trabalho, com base na negação do sofrimento no trabalho dos homens e dos animais. Mostrarei em seguida, a partir de resultados de pesquisas de campo ${ }^{1}$, que, apesar das profundas transformações do trabalho no setor da pecuária, os pecuaristas conservaram um laço afetivo com seus animais, laço que na maioria dos casos consideram como parte integrante de seu trabalho e construtor de sua identidade. No entanto, a perenidade da relação entre homens e animais no contexto atual das atividades de pecuária é causa de sofrimento, pois perdura em oposição às injunções contrárias e cada vez mais paradoxais do gerenciamento técnico, econômico e científico dos pecuaristas, e a uma organização do trabalho fundada na divisão do trabalho e no distanciamento do outro, humano ou animal.

\section{A PRODUÇÃO ANIMAL, UMA INDÚSTRIA COMO OUTRA QUALQUER}

Nas sociedades ocidentais, o desenvolvimento do cristianismo, a primazia do cartesianismo e, por fim, o desenvolvimento do capitalismo promoveram uma mudança radical na relação dos homens com a natureza e os animais. A Inglaterra no século XVIII e a França e os Estados Unidos no século XIX, em nome do Progresso e da Ciência, instau- raram com o animal de criação uma relação unilateral cujo objetivo essencial passou a ser o lucro. As fábricas e as siderúrgicas cuspiam suas mercadorias numa velocidade cada vez mais acelerada enquanto evoluíam e se racionalizavam os sistemas de pecuária. A zootecnia, ciência da exploração racionalizada dos animais domésticos, contribuiria para fazer de uma grande parte das atividades de pecuária um processo industrial especializado e rentável, e dos pecuaristas ligados a essa indústria operários ativos e aparentemente insensíveis a uma produção maciça de matéria animal ${ }^{2}$. Apartados de sua história e da de seus animais, trabalhando cada vez mais em "confinamento", ou seja, separados do meio natural, esses "produtores" deviam trabalhar num tempo otimizado e permanecer exclusivamente nos limites de sua cadeia de produção.

A vontade de industrializar a pecuária participa de um projeto nitidamente declarado e reivindicado pelos zootécnicos franceses do fim do século XIX, fundadores da disciplina. Industrializar é explorar industrialmente, ou seja, pelos meios e métodos da indústria, que é definida como o conjunto das atividades econômicas tendo por objeto a exploração das matérias-primas e a sua transformação em bens de produção ou de consumo. O que se pretende é, com a emergência da sociedade industrial na França, fazer a pecuária participar desse movimento e transformá-la, com o apoio da ciência, num conjunto de atividades coordenadas e rentáveis para a Nação. Esse processo, e as inovações técnicas que progressivamente estiveram a seu serviço, já havia se iniciado na Inglaterra e representava um modelo para muitos zootécnicos franceses. Notemos que esse objetivo industrial não parece ter obtido a adesão imediata dos pecuaristas, agrônomos e veterinários da época, como o confirma o próprio A. Sanson: "será difícil acreditar, no futuro, que essa maneira de colocar o problema zootécnico tenha podido ser considerada como revolucionária, e que tantos esforços foram necessários para que fosse admitida (...), não se terá como explicar que a produção animal tenha sido, há tanto tempo, encarada de outro modo do que como uma indústria obedecendo antes de tudo às leis econômicas, igual a todas as outras" (Sanson, 1907, p. 8). A crítica moral ao tratamento dos animais nesses sistemas industriais aparece conjuntamente a seu desenvolvimento, como o mostram, por exemplo, os comentários de L. de Lavergne sobre a "nova escola" da pecuária inglesa ${ }^{3}$ e o romance de Upton Sinclair dedicado ao trabalho na cadeia de produção de carne americana do início do século XX (Sinclair, 1906), e como a emergência na França das primeiras instituições de defesa dos animais deixa evidente ${ }^{4}$.

A "máquina animal zootécnica" é, portanto, o meio para se alcançar um fim que é a industrialização da pecuária e o aumento da produtividade dessa atividade: "a pecuária deve intensificar sua produção para terminar de preencher o 
déficit do pós-guerra, aumentar as unidades fornecidas pelo rebanho e conquistar, para os reprodutores de nossas melhores raças, o lugar no mercado mundial ao qual sua qualidade lhes dá direito. Para tanto a pecuária deve trabalhar tendo em vista o aumento do rendimento individual a fim de assegurar uma maior produtividade: pode-se até afirmar que o aumento do rendimento individual é um fator de produção mais eficaz que o aumento bruto do efetivo global. É portanto necessário orientar nessa direção todos os esforços dos pecuaristas" (Dechambre, 1928). O animal sendo uma máquina e a zootecnia a ciência da exploração racionalizada dessas máquinas, fica claro que "a perfeição para a organização da produção zootécnica consiste, como para a organização de toda a produção industrial, na divisão do trabalho, quer dizer na especialização dos animais" (Charnacé, 1869, p. 55).

Esse projeto industrial certamente não era perceptível para a massa atomizada dos pecuaristas que eram convocados ao "desenvolvimento" e que, principalmente na Bretanha, foram rapidamente "enquadrados" e orientados na direção desejada. O objetivo declarado no quadro institucional do desenvolvimento agrícola na França após a Segunda Guerra Mundial não era, com efeito, a industrialização da pecuária, mas a sua racionalização ou sua modernização, modernização essa que respondia para muitos agricultores a um desejo de melhoria de suas condições de vida e à perspectiva de uma "equiparação" de seu modo de vida com o dos habitantes das cidades: "Em 1956, os jovens agricultores, pela voz de Michel Debatisse, apoiaram essa nova orientação declarando-se, contra os mais velhos, favoráveis ao êxodo, à reforma das estruturas, à modernização" (Mendras, 1995, p 302).

O número de propriedades agrícolas na França, que era de 2,5 milhões em 1950, e de 1,3 milhão em 1979, é hoje de $664000^{5}$. Dentre elas 400 000, consideradas "profissionais", totalizam $95 \%$ do potencial agrícola ${ }^{6}$. As empresas de abate, 767 em 1980, são hoje 339, das quais a metade é constituída por abatedouros industriais privados que realizam $80 \%$ da produção. Cerca de 20 abatedouros essencialmente privados concentram $47 \%$ da produção (Fraysse et al., 2001). O processo de concentração das propriedades agrícolas e de intensificação do trabalho prossegue. As estruturas industriais atualmente implantadas visam reduzir a quantidade de trabalhadores e aumentar o nível de automação dos sistemas. Essa orientação é acompanhada de uma estratégia de deslocamento de uma parte da produção animal - sobretudo da engorda - para certos países da América do $\mathrm{Sul}^{7}$. No sistema industrial, o número de porcas que um casal ${ }^{*}$ de pecuaristas precisa criar para ter rentabilidade é hoje de cerca de 300. No mesmo quadro, o esforço que o animal deve fazer para (se) produzir foi consideravelmente aumentado. A produção média das vacas leiteiras aumentou em 41\% desde 1984, 75\% dentre elas encontramse em rebanhos de mais de 30 vacas. Graças à redução dos "tempos improdutivos" o número de leitões produzidos anualmente por uma porca é hoje de 24,6. Era de 20 em 1980 e de 16,7 em 1971. A renovação dos animais também se acelerou. Uma porca parte hoje para a reforma após dar cria menos de 5 vezes (2,5 anos).

\section{O "BEM-ESTAR ANIMAL": UMA PROBLEMÁTICA CIENTÍFICA CONSTRUÍDA COM BASE NA NEGAC̣ÃO DO SOFRIMENTO}

A temática do "bem-estar" na pecuária emergiu há cerca de vinte anos na França como um questionamento crítico das condições de vida dos animais em sistemas industrializados e das condições de trabalho das pessoas. A influência negativa desses sistemas do ponto de vista da saúde dos animais, e portanto de seu desempenho, é enfatizada por veterinários mas também por economistas, sociólogos e psico-sociólogos, estes últimos evidenciando os limites econômicos do processo de industrialização e os estragos que este provoca na saúde mental dos pecuaristas ${ }^{8}$. Entra-se desse modo num terreno crítico que diz respeito tanto aos homens quanto aos animais.

A partir da década de 1980, no entanto, o processo de industrialização é acelerado. De um ponto de vista científico, a questão do tratamento dos animais de criação em sistemas industriais é transformada, pelos especialistas, em problemática do "bem-estar animal", ou seja, em problema de pesquisa sobre a adaptação biológica e comportamental dos animais a esses sistemas. A questão das condições de trabalho dos pecuaristas e dos assalariados é, por sua vez, completamente minimizada, apesar das resistências de muitos pecuaristas ao processo de industrialização. Nas empresas de pecuária, a pressão produtiva se intensifica, ao mesmo tempo sobre os animais e sobre os homens, e normas de "bem-estar animal" vêm aparecendo como resultado, em pequena parte, dos trabalhos dos cientistas, que formulam suas perguntas em termos de estresse, de "preço a pagar", e de patamar de aceitabilidade social dos sistemas industriais e, em grande parte, do lobby europeu da proteção aos animais que desenvolve posições cada vez mais radicais contra a pecuária industrial e, às vezes, até contra a pecuária como um todo.

Passou-se portanto, no prazo de vinte anos, de uma crítica dos sistemas industrializados que era compartilhada por uma parte dos cidadãos, fossem eles pecuaristas, protetores dos animais ou pesquisadores, a uma situação cada vez mais conflituosa que opõe, em primeira análise, por um lado os pecuaristas e, por outro lado, os protetores dos animais, aos quais se junta, através da mídia, uma parte da sociedade, enquanto os cientistas se colocam como produtores de fatos 
objetivos. Essa evolução normativa que se realiza de modo pontual e sem coerência global do ponto de vista dos sistemas, não produziu de fato nada de positivo para a maioria dos animais, nem tampouco para os pecuaristas ou os cidadãos protetores dos animais. Ao contrário, ela tende a intensificar o trabalho e a alargar o fosso entre os pecuaristas e seus animais, pela organização coletiva do trabalho em sistemas industriais e intensificados. Ao normalizar o trabalho a partir de critérios de adaptação, de aceitabilidade e de visibilidade social, contribui sobretudo para transformar dores visíveis em sofrimentos invisíveis, tanto para os homens quanto para os animais.

Para as cadeias de "produção animal", o "bem-estar animal" se inscreve no processo das indústrias da carne ${ }^{10}$ em termos de resposta de marketing à sensibilidade dos consumidores. $\mathrm{O}$ animal é, de seu nascimento à sua morte, considerado como matéria animal in fine transformada em produto de consumo. As condições de trabalho nos sistemas industriais são questionadas no âmbito das cadeias de produção apenas do ponto de vista dos limites de rentabilidade que podem causar (Porcher, 2001). A brutalidade costumeira com os animais tende a ser depreciada a favor de condutas "suaves" por ser um fator de estresse e porque o estresse é um fator de degradação da qualidade da carne. Assim vê-se um centro de formação propor aos técnicos do gerenciamento de criações de porcos um "pacote de formação 'comportamento e produtividade' "permitindo aplicar junto aos pecuaristas uma "lista de verificação de auditoria do estresse" e implantar "estratégias de melhoria". Essa contradição entre a violência intrínseca do sistema à qual estão submetidos homens e animais - acrescida pelo aumento das cadências e a intensificação do trabalho - e as injunções de "suavidade" e de assunção do "bem-estar animal" é igualmente perceptível na organização do trabalho nos abatedouros: "é verdade que quando tem um carregamento de porcas de reforma, se por acaso o motorista já chegou, bom, ele não vai ficar duas horas esperando, porque ele também tem o seu horário, então, certamente tem que andar, têm sempre os mesmos parâmetros para a gente respeitar, porque ele não vai prestar contas falando que uma porca não queria andar, precisei de 3 horas para carregar ela porque os patrões não vão falar para ele sinto muito, não vai ficar por isso, então é isso a gente bate em cima, tem que andar ${ }^{l 1 "}$ "; "...porque de todo jeito quando a gente tem um animal num corredor e ela não quer andar, bom, a gente é obrigado a fazer alguma coisa porque a gente tá aí pra isso, são 30 animais ${ }^{12}$ por hora que a gente tem que pôr lá dentro, para matar então de algum jeito tem que fazer elas andarem"; "é bem verdade que às vezes acontece, mas tem vez que a gente não tem escolha, se a gente levar 15 minutos para empurrar um porco, depois a gente leva bronca lá na linha, porque depois ficam buracos".
Os sistemas industriais de produção são concebidos como se o pecuarista ou o assalariado fosse um ser inteiramente conduzido por uma racionalidade unicamente econômica, e como se o animal fosse um objeto sem vida, inexistente, mesmo sendo com toda evidência um ser biológico, já que tem necessidades fisiológicas. O gerenciamento técnico-econômico dos pecuaristas funciona na base dessa racionalidade, enquanto do ponto de vista dos pecuaristas, no entanto, a parte afetiva na criação de animais é descrita como um elemento central do trabalho.

Para os pecuaristas, entre os quais uma grande maioria (86\%) percebe hoje a si mesmo como sendo "um elo de uma corrente", a diferença entre o trabalho prescrito pela organização do trabalho nas cadeias de produção e o trabalho real, tal como é vivido no cotidiano com os animais, é imensa. A companhia cotidiana dos animais, os cuidados, a atenção e, para uma grande parte dos pecuaristas, a afeição que estes têm pelos animais se coloca em completa contradição com os procedimentos de "produção animal". Para os pecuaristas, o trabalho real é desenvolvido com os animais e uma grande maioria deles não confunde o animal e a carne, pois "a arte do açougueiro não define a arte do pastor"13.

\section{A RELAC̣ÃO DE TRABALHO ENTRE PECUARISTAS E ANIMAIS: UMA INEVITÁVEL PRESENC̣A DA AFETIVIDADE}

Meus resultados de pesquisa evidenciam um forte investimento afetivo dos pecuaristas em relação a seus animais. Esse investimento se expressa, de modo coerente, pelo viés das representações que os pecuaristas fazem de seus animais e de seu ofício, e pela maneira como descrevem os elementos relacionais ligados ao trabalho. Meu trabalho permitiu ressaltar dois grandes tipos de atitudes dos pecuaristas em relação a seus animais: uma atitude descritiva de relações de amizade que reúne representações positivas do status do animal, a expressão de um laço afetivo entre homens e animais, e de condutas de negociação no trabalho; uma atitude descritiva de uma relação de poder reunindo representações reificadas do animal de criação, uma denegação do laço afetivo e da comunicação com os animais ligada à afirmação de um primado da racionalidade econômica sobre os sentimentos, e a expressão de uma dominação no trabalho sobre os animais. As representações do animal e de si mesmo e o investimento afetivo no relacionamento com os animais têm uma influência preponderante sobre as condutas das pessoas e, em conseqüência, sobre o comportamento ${ }^{14}$ dos animais. No entanto, o real vivido no trabalho construído pelo sistema de produção e pela organização coletiva do trabalho, conforme permita, ou não, ao pecuarista trabalhar em coerência com suas 
representações e sua afetividade, promove uma ação construtiva ou destrutiva de primeiro plano.

\section{- "... em vez de duas patas, tem quatro"}

Os resultados das pesquisas mostram que a característica primeira dos animais de criação, perceptível principalmente quando se trata de mamíferos, é ser vivo, e ser vivo fundamentalmente da mesma maneira que os seres humanos. A capacidade dos animais em sentir prazer e sofrimento e em expressá-lo sem ambigüidade funda essa percepção que se encontra formulada nas numerosas analogias presentes no discurso dos pecuaristas: "para mim, um animal, tem que cuidar dele quando está doente, é preciso cuidar dele, tem que ter comida suficiente, tem que, tem que cuidar dele como de um ser humano, é a mesma coisa" ${ }^{15}$. Esse status de ser vivo sensível permite que sejam instauradas relações de comunicação individualizadas e diferenciadas, vivenciadas como muito similares àquelas que podem existir entre os seres humanos: "Tenho Boulben (um porco reprodutor), em bretão quer dizer: cabeça dura, carrancudo, pronto para atacar, e combina muito bem com ele; Lutune, ele, o duende das montanhas, é o cara, digo: o cara, tenho impressão que a gente meio que quer ter um relacionamento quase humano com os seus animais..."; "Têm uns relacionamentos que se instalam, é meio como com as pessoas, quando se conversa com as pessoas... é meio a mesma coisa, em vez de duas patas, tem quatro"; "a gente sente o animal na defensiva que sempre vai deixar a gente do lado de fora ou um animal com quem a gente está em acordo, é como com as pessoas... tem pessoas com quem a gente está bem, a gente pode simpatizar, ou até a gente pode passar a vida inteira com elas, e outras não"; "A gente tem a Dauphine, mas a gente tem a Marguerite; uma das nossas filhas tirou uma foto com o vestido de noiva com a vaca atrás. É que é uma vaca muito bonita, tem personalidade, é uma bela vaca".

Inversamente, e de maneira minoritária nas pesquisas que realizei, o estatuto do animal pode ser percebido como essencialmente diferente daquele do ser humano, ou seja, do pecuarista enquanto ser humano: "não, a gente não respeita os porcos como os humanos dos quais a gente faz parte, não me ponho no lugar dos porcos... não faço parte dessa categoria”. O animal é então descrito, não como um parceiro, mas como uma ferramenta de trabalho ${ }^{16}$ : "a vaca leiteira é uma máquina de produzir leite"; "uma galinha é uma máquina de fazer ovos"; "é uma ferramenta de trabalho como outra qualquer".

\section{- "...a vida de um homem a serviço dos seus animais"}

O pecuarista constrói representações de si enquanto ser humano e enquanto pecuarista de acordo com suas representações do animal e em função do sistema de produção.
De maneira majoritária nos resultados de minhas pesquisas, a posição do pecuarista em relação a seus animais remete muito mais a representações ligadas ao sentimento de ter responsabilidades e deveres com os animais do que a representações de dominação e poder. O sentimento majoritário que os pecuaristas têm de estar a serviço de seus animais ${ }^{17}$ é, aliás, coerente com a idéia de que estes são indivíduos sensíveis do mesmo modo que seres humanos; seu estatuto de animais de criação torna-os dependentes, mais ou menos segundo o sistema de criação, o investimento dos pecuaristas em relação a eles. A deontologia do ofício baseia-se então sobre o compromisso dos pecuaristas com seus animais e sobre a percepção de uma relação de troca, que pode ser analisada, a meu ver, em referência à teoria do dom: "Vou ficar... para manter meus compromissos de criador, para não largar os animais"; "é a vida de um homem com seus animais, quem sabe a vida de um homem a serviço dos seus animais, quem sabe seja mais isso"; "estão plantados aí, se a gente não cuida deles ao máximo, para que então ter um animal. Porque um ser humano, ele, sofre e ele conta, não é?, mas um animal não só ele dá o nosso sustento mas ainda a gente tem que respeitar ele pelo sustento que ele nos dá".

Um pecuarista que representa seus animais como seres vivos, sensíveis, em relação a quem está moralmente comprometido e com quem está em relação de comunicação, demonstra igualmente um forte investimento afetivo em relação a eles. Essa base afetiva enraíza-se provavelmente na infância (Salmona, 1994: Soriano, 1985), como confirma uma maioria de pecuaristas nas minhas pesquisas ${ }^{18}$ : "(quando voltava da escola) antes de ir beijar a minha mãe, eu ia ao estábulo para ver as vacas". A presença dos animais na vida das pessoas é descrita como constitutiva de sua identidade. Participa de seu bem-estar físico e psíquico e do sentimento de estar presente no mundo, ou seja, de estar vivo, de uma maneira essencial e autêntica. As expressões "ter nascido em", "ter se banhado em", "ter sido criado em" mostram o quanto a relação com o animal é percebida como um evento íntimo e interiorizado. "O animal, ele faz parte de você" é de fato claramente expresso e explicitado pela metáfora genética: "a gente tem nos genes alguma coisa colada, um tanto de DNA a mais, e esse DNA quer dizer que a gente é criador". O DNA a mais, é a parte animal que os pecuaristas receberam e que explica que eles são pecuaristas; "aquilo aguardava dentro de mim”. Essa impressão, que está inscrita dentro do corpo, explica o apego que os pecuaristas podem ter por seus animais: "Vai ser duro (a reforma) porque, bom, a gente se apega a seus animais no fundo". O apego ao animal não provém de uma escolha, mas de uma necessidade interior e do trabalho com os animais.

O apego se constrói na reciprocidade: "o contato, ele é recíproco". Essa parte animal dentro do pecuarista, o ani- 
mal a reconhece. A relação pode então ser descrita como uma osmose: "é preciso que haja uma certa osmose" ou, como escreve Erwin Straus ${ }^{19}$, uma compreensão simbiótica. Para Straus, a relação com o animal provém efetivamente do "sentir" e não da representação: "é no mundo do sentir que encontramos os animais, pois o mundo é compartilhado pelo homem e o animal. É no âmbito desse mundo que compreendemos o animal, e fato mais significativo ainda, que o animal nos compreende" (Straus, 1935, p. 234). A compreensão simbiótica, escreve Straus, só pode se desenvolver se, na relação com o animal, uma dupla possibilidade - fugir ou seguir - lhe é oferecida. Esse "fugir ou seguir" remete igualmente à noção de apego (Bowlby, 1978). A busca de proximidade, de contato, o following (acompanhamento) são elementos de comportamento que mediam o apego e que revelam uma relação de confiança entre pecuarista e animais. A afetividade - e isto fica claro nas citações acima, onde não se pode deixar de perceber uma profunda ternura pelos animais - modelou esses pecuaristas e constrói sua relação com o mundo animal. Entende-se portanto como a morte dos animais destinados ao abate, ou aquela por reforma ou por razões sanitárias, nunca é algo simples.

\section{- "... levar os animais ao abatedouro, para mim, é o pior"}

Meus resultados de pesquisa mostram que para um em cada dois pecuaristas o abate dos animais é um momento difícil, e não algo óbvio ${ }^{20}$. Com efeito, a morte dos animais é muitas vezes vivida como o último contra-dom ao qual o animal é forçado, a contraparte do prazer vivido juntos, o lado ruim da moeda: "tem que tentar não pensar... a gente se obriga a não pensar, tem porcas que a gente guarda um pouco às vezes por sentimento, porque é difícil, então a gente tenta ficar com elas mais um pouco, algumas porcas deixar elas irem, é duro, é o lado ruim, é a contraparte...”; “(os porcos para embutidos) é a parte que dá mais dinheiro, a parte que paga o resto, de todo jeito não dá para ter ilusão, os animais a gente não pode criar eles para ficar com eles"; "o abatedouro é fora das minhas capacidades... bom, vai ter que matá-lo é o jeito, tem que sangrá-lo, mas deixo o lugar para outros"; "o abatedouro, tem um lado um pouco sórdido, é bem claro, tem um fim que não é sempre o que muitos animais mereceriam": "o pior de ser criador, é levar os animais ao abatedouro, para mim, é o pior".

Ao contrário, para um em cada dois pecuaristas, o abate dos animais faz parte do ofício ou da rotina do trabalho: " $a$ gente liga para o abatedouro, a gente tem tantas porcas para reformar, é programado, para os embutidos a cada quinze dias, a gente está acostumado, tem que telefonar, tem tantos porcos que têm que ir embora, é uma rotina que a gente já tem".
Os pecuaristas se colocam, para (se) autorizar a morte do animal, um conjunto de justificativas que voltam em parte a aparecer entre as pessoas trabalhando nos abatedouros: coletivamente, a gente cria animais para comê-los, antes de comêlos é preciso matá-los, mas "se não houvesse sua morte, não haveria sua vida". A morte do animal aparece para certos pecuaristas como o preço a pagar pela relação, pois, em nível individual, criam-se animais para criar animais, não se cria animais para matá-los. O que remete, do ponto de vista das relações entre homens e animais de criação, a uma primazia do laço afetivo sobre o interesse econômico, e a um fim em si dos procedimentos de criação, do ponto de vista do próprio pecuarista, e mais amplamente provavelmente do ponto de vista da sociedade, como o comprova o status do animal "de estimação" nas sociedades ocidentais.

Muitos pecuaristas instauram então estratégias visando minimizar o mais possível as situações de sofrimento para os seus animais: "quando posso, eu mesmo os levo ao abatedouro. Dou um jeito com o pessoal do abatedouro para entrar pelo que chamo a porta dos fundos, quer dizer para não passar pelo estábulo, esse lugar de espera onde os animais permanecem às vezes por um ou dois dias, onde tem esse horrivel cheiro de morte que paira, onde a gente vê certas vacas com um olhar que parece cheio de sabedoria... é um lugar que eu não gosto e não quero que os meus animais permaneçam lá”.

\section{"A GENTE NÃO PODE MAIS LIGAR PARA OS SENTIMENTOS AGORA, O LADO ECONÔMICO TEM DE MANDAR DE QUALQUER JEITO"}

A repressão da afetividade e a desconstrução das relações entre homens e animais no trabalho apoiaram-se em mudanças radicais de modelos de representações dos animais e do ofício de pecuarista, e em transformações profundas dos sistemas de produção e da organização coletiva do trabalho. Essa repressão, que perdura hoje sob formas menos visíveis, é a causa de um sofrimento no trabalho ainda mais forte por ser negado pelas estruturas profissionais e ter-se tornado inexprimível para os pecuaristas.

Vou me deter aqui sobre os elementos preponderantes da organização coletiva do trabalho e do funcionamento dos sistemas de produção industriais e intensificados que são causas de sofrimento por repressão da afetividade e ruptura de comunicação, por perda dos comportamentos livres no trabalho, mas também por falta de reconhecimento social e por incertezas morais.

\section{- Desqualificação da afetividade e degradação da comunicação}

O investimento afetivo dos pecuaristas em relação aos seus animais, que constituía historicamente um freio à 
intensificação e à industrialização da pecuária, foi representado aos pecuaristas como uma sensibilidade fora de propósito e arcaica, uma "fraqueza" de sua parte, um handicap ao desempenho técnico-econômico penalizando a rentabilidade da indústria e a competitividade das cadeias de produção. A ideologia utilitária e os valores técnico-econômicos do modelo liberal são assumidos pelos sistemas de gerenciamento dos pecuaristas como as únicas referências coletivamente validadas capazes de garantir a renda do pecuarista e a perenidade da empresa. Sentimentos e rentabilidade são descritos como antinômicos, sendo que o lugar dos sentimentos no trabalho é vivenciado como legítimo pela maioria dos pecuaristas ${ }^{21}$. "Ligar para os sentimentos" é percebido por muitos deles como um defeito pessoal, um distanciamento em relação aos outros pecuaristas ou aos gestores do sistema, uma emoção da qual é preciso desconfiar, pois é inadequada ao atual contexto do trabalho na pecuária. $\mathrm{O}$ mundo humano do dinheiro e do interesse pode desse modo se opor ao mundo animal dos sentimentos e das emoções com o qual muitos pecuaristas tendem preferencialmente a se identificar: "algumas vezes, bom, enfim eu nem sempre raciocino como homem de negócio, sendo que hoje em dia todo mundo raciocina como homem de negócio, mas têm vezes que a gente liga para os sentimentos, as pessoas me falam, você liga demais para os sentimentos, é isso, porque vocêficou com isso, porque. É isso aí. A esse nível, acho que eu me diferencio, e meu irmão é a mesma coisa, a gente se diferencia, porque a gente liga para os sentimentos, é isso aî"; "então pode ser que a gente ligue para os sentimentos com as porcas mas enfim enquanto elas estão bem então a gente fica com elas, e também a gente gosta delas... não se pode sacrificar todo mundo sob pretexto de rentabilidade"; "É a grana, os relacionamentos, os sentimentos, muitas vezes isso fica para trás, tem isso tudo que é difícil de agüentar enquanto que ao nível animal é muito mais sadio, muito mais limpo é claro, não sei como dizer, é natural".

A desqualificação da afetividade conduz a uma degradação da comunicação entre pecuaristas e animais, e a uma deterioração das relações entre pecuaristas. Os sistemas industriais, valorizando a competição, apresentando os resultados em termos quantitativos, comparativos e positivos, opondo "os melhores" ("grupo dos vencedores", grupo "superior"...) aos outros, aos "menos bons" 22 , e difundindo na imprensa profissional a ideologia da "guerra econômica" na qual os pecuaristas deveriam estar engajados de corpo e alma para seu próprio bem e o das exportações do setor agroalimentício francês, constroem representações do outro pecuarista, do vizinho, não como um colega, um par solidário, mas como um concorrente potencialmente perigoso, até mesmo um inimigo a eliminar: "não se pode confiar mutuamente entre criadores, porque num certo momento entramos na dança, copiamos os planos do vizinho. Quer a gente esteja na turma do mais forte ou do mais fraco, a gente não se sente a vontade em relação ao outro, a gente não sabe como é o outro... o vizinho (pecuarista) a partir do momento que ele existe, ele extrapola”. Esse estado de espírito, que requer o esmagamento dos valores morais mais elementares, estende seus efeitos ao conjunto das relações profissionais dos pecuaristas, como o demonstram por exemplo os transportadores de animais: "o mais difícil, é agüentar os fazendeiros, maior o tamanho, mais idiotas são (...) no fim das contas, isso é o mais difícil, e tem que ficar quieto (...) a gente acostuma, e também eles gostam de fazer a gente de besta, a gente não pode ligar para isso, faz parte do ofício (...) pelo menos dizer bom dia, boa tarde, é difícil para eles dizer bom dia, boa tarde, só isso... além de tudo, entre eles, eles se pegam também. Entre eles, é maluco, se podem acabar com um outro, eles fazem... são todos estressados, todos nervosos". Essa situação é tanto mais dolorosa para certos transportadores, principalmente de bovinos, que escolheram esse ofício porque eles "gostam de contatos".

O sofrimento dos animais na pecuária e, no mínimo, a "insatisfação" que expressam os pecuaristas e os assalariados não provêm de falhas individuais, mesmo sendo esse sofrimento subjetivo, mas do sistema produtivo. Não é o indivíduo que está louco, doente ou afetivamente inapto, mas de fato a situação na qual ele se encontra ${ }^{23}$. O sentimento de incompetência que pode experimentar um assalariado porque "não consegue" estar em sintonia com a violência do sistema, por exemplo, batendo nos animais, mostra que este impõe práticas em contradição com os comportamentos espontâneos não-violentos da maioria das pessoas: "nunca consegui perder a calma com um animal, uma vez perdi a calma, e pronto, mas na hora de bater nela, nem consegui, nem pude bater nela, no entanto fiquei brava, fiquei nervosa, gritei tudo que podia, mas não consegui bater nela (...) Mas aí, não é minha fazenda, portanto não sou eu que mando, portanto é verdade que se querem bater, eles batem, mas eu, na minha fazenda, eu teria deixado ela no corredor a noite inteira e no dia seguinte teria tentado de novo. É isso que eu teria feito. Mas é verdade que lá não sou eu que decido, então lá elas têm que entrar, não tem conversa, lá eles têm mais o que fazer já que sempre estão correndo, então lá ela entrou. Foram precisos dois homens, com uns escudos, dominaram ela, levaram ela até sua manjedoura então no fim empurraram ela, bem, mas eles têm uma força que eu não tenho."

\section{- Perda dos comportamentos livres no trabalho e não-reconhecimento social}

Meus resultados de pesquisa evidenciam o profundo sentimento de angústia experimentado pela maioria dos pecuaristas no trabalho e em relação ao seu ofício. Privados 
de seu poder de decisão ${ }^{24}$, dependentes das orientações da Comunidade Européia e dos prêmios, criticados pela mídia, desacreditados pelos poderes públicos, obrigados a práticas que o número crescente de animais ${ }^{25}$ torna cada vez mais pesadas $^{26}$, a maioria dos pecuaristas se sente engolidos por um trabalho cujas regras lhes escapam em grande parte, mas das quais percebem que não lhes deixam "direito a $\operatorname{erro}^{27}$ ". Para muitos deles, além disso, o laço entre a vida familiar e a vida profissional se torna difícil. Os relacionamentos da vida privada sofrem da sobrecarga de trabalho e da tensão à qual são submetidos os pecuaristas ${ }^{28}$. A situação de pressão produtiva, a necessidade de ir rápido, o sentimento de nunca ter terminado, de não ter tempo para fazer tudo... andam juntos com o sentimento intimo de fazer um "trabalho sujo", do ponto de vista do olhar social, e no entanto de fazer "o melhor que pode" de seu próprio ponto de vista.

O sentimento de frustração em relação ao ofício, expresso por uma maioria de pecuaristas, e cuja realidade é absolutamente visível na organização do trabalho, pelas cadeias de produção e na história do desenvolvimento agrícola desde o século passado, é todavia acompanhado pela expressão de um sentimento inverso de autonomia e de prazer no trabalho. Assim, se $74 \%$ dos pecuaristas interrogados dizem estar de acordo com a afirmação "não sou eu que decido, é Bruxelas", $84 \%$ afirmam também "sou eu que escolhi inteiramente o meu sistema de produção". Da mesma maneira $68 \%$ estão de acordo com "nunca tem nada de garantido nesse trabalho, isso me angustia", $73 \%$ estão com "meu trabalho é principalmente momentos de grande felicidade" enquanto que $66 \%$ estão em desacordo com "se fosse começar de novo, escolheria um outro ofício". Na aparente contradição dessas respostas pode-se ler tanto o sentimento de uma frustração quanto a reivindicação defensiva de uma autonomia de decisão ${ }^{29}$, e, ao mesmo tempo, a afirmação do apego a um trabalho provedor de "momentos de grande felicidade". Esse trabalho gerador de felicidade não é o trabalho prescrito pelos procedimentos que é por sua vez provedor de incertezas e angústia: "me pergunto se esse trabalho ainda tem algum sentido"; "não faço mais o ofício que escolhi, agora não sou mais um criador, sigo o padrão", mas o trabalho autônomo do pecuarista, aquele onde se expressa sua criatividade, sua afetividade, sua capacidade de entrar em relação com os animais e de fazer algo único. O sentimento da felicidade, que se refere a elementos particulares da vida, anda junto com o desejo de que o evento que promove esse sentimento possa durar. É por isso que, a meu ver, dois terços dos pecuaristas mantêm ao longo do tempo uma relação positiva com seu ofício.

A industrialização das atividades de pecuária levou muitos pecuaristas a dirigir um olhar crítico sobre seu ofício, apoiado de maneira antagônica pelos discursos negativos da mídia, principalmente do ponto de vista do meio ambiente e da relação com os animais. A vergonha vivenciada pelas pessoas confirma essa perspectiva crítica. A vergonha é um sentimento moral subjetivo, como ressaltam Marx - "a vergonha é uma espécie de cólera voltada contra si”" ${ }^{30}$ - e Gaulejac - "a vergonha revela a intimidade de cada ser, sua subjetividade profunda... a vergonha é um sentimento social que concerne à identidade do sujeito, ou seja que o constitui enquanto membro efetivo de uma sociedade, afirmando ao mesmo tempo sua singularidade e seu pertencimento". Quando $70 \%$ dos pecuaristas interrogados se dizem de acordo com a afirmação "o cúmulo da vergonha para um pecuarista é ter um produto que ele não ousa comer" e $64 \%$ com a afirmação "me sinto meio com vergonha das condições na quais vivem certos animais de criação", não podemos deixar de notar que ao mesmo tempo em que são a expressão de um sentimento de indignidade coletiva, essas respostas pedem uma mudança das relações entre homens e animais construídas pelos sistemas "vergonhosos", pois "a vergonha nos faz recair no mundo. Não no mundo efêmero das imagens virtuais, mas no das relações intersubjetivas e da comunicação interpessoal. 'Luz íntima da subjetividade', ela nos convida a recusar os faz-de-conta e a procurar na qualidade dos contatos com outrem e desenvolvimento da auto-estima"(Gaulejac, 1996, p. 340 e seg.).

O sentimento de vergonha é experimentado pelas pessoas em função do ofício de pecuarista. Fica-se pessoalmente envergonhado por criar vitelas aos montes: "a vitela para o abate é uma heresia para mim, faço isso porque a gente está num país onde se faz vitela para o abate", ou se sente vergonha pelo outro, e pessoalmente enquanto criador, ao ver outros aceitarem aquilo que razões morais nos impedem de aceitar: "Eu sei que ele tem vergonha daquilo que faze isso me deixa mal"; "Então, ele me dizia, eu faço isso, você sabe é meu trabalho, não é complicado, eu contrato de manhã a tal hora, eu demito de noite a tal hora, era só o transporte... ele vivia disso, ele não vivia mal, mas aí ele parou depois disso, então eu acho que sobre o plano humano não devia ser muito legal no fundo. Mas ele falava que ele se lixava, fazer isso ou outra coisa, sua mulher era a mesma coisa, ela se lixava. Mas fiquei impressionada porque o Jacques me contou, o que eu posso te dizer é que eu nunca como vitela. Nunca compro. É maluco. E eu não entendia e ele não comia pelas mesmas razões que eи com as minhas cabras; era porque, bem, ele achava que não podia fazer bem. Eu me dizia, os pobres animais, puxa vida. E aí, eu brigava muitas vezes com o meu marido porque eu dizia que era inadmissível e meи marido dizia sempre que a gente era obrigada a chegar nisso. Que as necessidades tinham levado a fazer esses sistemas de criação. Mas não, para mim, isso não teria me interessado".

Se a industrialização da pecuária modificou profundamente as maneiras de "criar" os animais, ela também trans- 
formou completamente as atividades de abate. A diminuição drástica do número de abatedouros, seu aumento de tamanho e seu afastamento da fazenda tornam cada vez mais difícil para o pecuarista um acompanhamento do animal. A obrigação de delegar $o$ abate às grandes unidades industriais é para muitos pecuaristas a causa de um sentimento de culpa em relação a seus animais, tanto mais forte que se sentem impotentes ante essa evolução, e eventualmente há aqui também um sentimento de vergonha provocado ao mesmo tempo pela decisão de reforma, principalmente quando esta não se baseia na vontade autônoma do pecuarista, e pelo abandono do animal às estruturas de abate.

O sentimento de vergonha acompanha a percepção de um isolamento social e a idéia de uma negação de suas dificuldades por parte dos "citadinos", essencialmente representados pela mídia. O sentimento majoritário que os pecuaristas experimentam então ante as críticas dos consumidores e dos cidadãos é o de uma profunda incompreensão. Assim, 80\% dos pecuaristas estão em desacordo com a afirmação: "as críticas da mídia são algo relativamente positivo para a pecuária”. O não-reconhecimento de seu trabalho é uma demonstração de sua "inutilidade". A rejeição de um ofício cuja vocação nutridora permanece primordial nas representações é uma causa de sofrimento para os pecuaristas. Como demonstra a evolução de certas atitudes dos ecologistas na Grã Bretanha, a agricultura pode ser percebida como "algo prejudicial do qual deveríamos nos livrar" (Cox, 2001, p. 19); o trabalho dos agricultores e dos pecuaristas é não somente desvalorizado, mas negado na sua própria essência. A vocação fundadora de "nutrir os homens" que faz o orgulho de grande parte dos pecuaristas transforma-se numa produção destruidora da natureza, da saúde dos homens e dos animais... da qual seria necessário se livrar para sobreviver.

\section{CONCLUSÃO}

A banalização institucional de condutas contrárias ao respeito de outrem (incitação à mentira, à delação, à reificação do outro, às manipulações psicológicas, ao abuso do poder...) é amplamente evidenciada, no quadro das relações humanas no trabalho, pela psicodinâmica do trabalho. Não se constata afinal entre os assalariados uma aceitação dessas novas "regras" do trabalho (cuja primeira, e quem sabe a única, parece definitivamente ser: o fim justifica os meios) e uma cisão da personalidade, uma clivagem, entre a pessoa no trabalho e a pessoa fora do trabalho, que lhe permite funcionar mentalmente de maneira totalmente diferente com seus colegas ou com sua família, e escapar ao sofrimento moral tornando impossível o encarar a si mesmo que permitiria reconhecer em nós o canalha banal que aceitamos ser com certa rapidez ${ }^{31}$ ? As condições de aceita- ção pelos pecuaristas ou pelos assalariados das condições de trabalho em sistemas industriais e os efeitos do trabalho sobre a saúde mental das pessoas requerem ser estudados. Com efeito, se o sofrimento dos animais nesse tipo de sistema é reconhecido e dá lugar a debates e a certas evoluções técnicas dos sistemas, o efeito dos procedimentos do trabalho industrial sobre a saúde física e psíquica dos pecuaristas e dos assalariados permanece ainda muito desconhecido.

Contrariamente à perversão das relações entre seres humanos no quadro do trabalho, é quem sabe a especificidade do trabalho de pecuária, ou seja, a parceria com o animal, que pode permitir, a meu ver, a salvaguarda entre a maioria dos pecuaristas do conteúdo relacional do trabalho e a persistência de um olhar moral sobre o conteúdo do trabalho. Com efeito, e como o ressaltam muitos pecuaristas: "os animais não são falsos; o animal não engana, ele não faz nenhum jogo"; ele é ele próprio autenticamente. Essa autenticidade é percebida por muitos como uma riqueza muito grande da relação com o animal. Como observa Erwin Straus: "o animal não pode mentir, não pode deixar de ser autêntico. Mas tampouco pode ser verdadeiro no sentido do homem que, pela generalização e a repetição, volta a si mesmo" (Straus, 2000, p. 377). A impossibilidade da perversão mental do animal nas relações de comunicação, sua não-participação na mentira, sua força de inércia ante a violência dos sistemas ${ }^{32}$ são um apelo constante ao respeito, à simpatia, à empatia. Levantarei a hipótese de que a permanência do real dos sentimentos e das emoções no animal salva os pecuaristas do desamor e permite que permaneçam humanos no trabalho, ou seja, que permaneçam lúcidos e capazes de sofrer com as práticas imorais que impõe uma organização do trabalho "desencarnada".

A forte tendência dos sistemas de produção animal que visa aumentar a distância entre os animais e os homens e conceber unidades de produção cada vez mais automatizadas inscreve-se numa perspectiva industrial e biotécnica, apoiada pelas "ciências da vida" ${ }^{33}$, erradicando sofrimento e prazer e desfigurando a vida. Não se pode deixar de constatar, cada vez mais, o domínio dos bio-poderes sobre nossas existências e a ignorância em que nos encontramos do que está verdadeiramente em jogo no tratamento científico-econômico-técnico do vivo sob todas as suas formas. As quimeras produzidas no sigilo dos laboratórios participam do processo de desumanização e de desnaturação iniciado pela implantação de uma agricultura industrial ${ }^{34}$. Nesse universo produtivo "desnaturado", ", os "animais" geneticamente modificados para serem adaptados aos sistemas industriais (sem olhos, sem patas, sem almas?) não sofrerão mais por não serem, e ninguém mais saberá na verdade quem são; os produtores e gestores desse material animal 
privados de relação com os animais tampouco sofrerão, nem por eles mesmos - ou não mais do que um operador de produção de material de informática - nem por fazer sofrer. Pois, como escreve Whitman: "nada é criminoso para nós senão nós mesmos, o que quer que seja que apareça, o que quer que seja que deixe de aparecer, somos admiráveis ou criminosos em relação a nós mesmos unicamente, se nos perdemos, não é nenhum outro vencedor que nos terá aniquilado, é por nosso próprio erro que desceremos na noite eterna" (Whitman, 1972, p. 371).

\section{Tradução: Giliane Ingratta}

\section{- Bibliografia}

BAUDEMENT Emile, 1869, Les mérinos. Librairie d'éducation et d'agriculture C. Delagrave.

BERLAN Jean Pierre et al., 2001, La guerre au vivant. Organismes génétiquement modifiés et autres mystifications scientifiques. Editions Agone/Editions Comeau et Nadeau.

BOWLBY John, 1978. Attachement et perte. L'attachement (volume 1). Le Fil rouge. Editions PUF

CANETTI Elias, 1978, Le territoire de l'homme. Le livre de poche. Editions Albin Michel.

CHARNACE Guy de, 1869, Considérations générales sur l'espèce ovine, dans Emile BAUDEMENT, 1869, Les mérinos. Librairie d'éducation et d'agriculture C. Delagrave.

COLSON François, 1980, Modernisation de la production porcine : les limites économiques au processus de rationalisation de l'élevage porcin. Journées de la Recherche Porcine 1980. p. 59-71.
COX David, 2001, Lagriculture, une nuisance dont on ferait mieux de se passer, dans Courrier International n 542 , semaine du 22 au 28 mars 2001

DAMIEN M., KASTLER A., NOUET J.C., 1981, Le grand massacre. Editions Fayard.

DANTZER Robert ; MORMEDE Pierre, 1979, Le stress en élevage intensif. Editions Masson/INRA.

DECHAMBRE Paul, 1928, Traité de zootechnie. Librairie agricole de la maison rustique, Librairie des sciences agricoles.

DEJOURS Christophe, 1993. Travail usure mentale. Editions Bayard.

DIRY Jean-Pierre, 1985, L'industrialisation de l'élevage en France. Editions Ophrys.

ENCYCLOPÉDIE DES NUISANCES, 1999. Remarques sur l'agriculture génétiquement modifiée et la dégradation des espèces. Editions de l' Encyclopédie des Nuisances. Paris.
FARRACHI Armand, 2000, Les poules préfèrent les cages. Editions Albin Michel.

FRAYSSE J., D'HERBOMEZ J.P., SOLER P., 2001, Les abattoirs d'animaux de boucherie: évolution depuis 1990 dans Renc. Rech. Ruminants, 2001, 8 p 31 .

GAULEJAC Vincent de, 1996, Les sources de la honte. Desclée de Brouwer.

MENDRAS Henri, 1995. Les sociétés paysannes. Folio. Histoire. Editions Gallimard.

PLATON, La république I/345c, 1996 Editions Garnier Flammarion.

PORCHER Jocelyne, 2001, L'élevage industriel des porcs: souffrance des animaux, souffrance des hommes, dans Burgat F. et Dantzer R., 2001 (coord.), Les animaux d'élevage ont-ils droit au bien-être? Inra Editions, p. 25-64

SALMONA Michèle, 1994, Souffrances et résistances des paysans français. Editions L'Harmattan.
SANSON André, 1907, Traité de zootechnie, tome I. Librairie agricole de la maison rustique.

SIGAUT François, 1990. Folie, réel et technologie, dans Techniques et culture $\mathrm{n}^{\circ} 15$, pp 167-179.

SINCLAIR Upton, 1906, The jungle. Site Internet de l'Université Berkeley de Californie (Berkeley digital library sunsite).

SORIANO Véronique, 1985. Choisir et réussir son élevage ou le roman de la technique et de la passion. DGER. CFPPA Le Rheu.

SPAEMANN Robert, 1996, Téléologie de la nature et action humaine, dans Etudes phénoménologiques $n^{\circ} 23-24$ Editions Ousia.

STRAUS Erwin, 2000 (1935), Du sens des sens. Editions Jerôme Million.

WHITMAN Walt, 1972 (1855). Feuilles d'herbe. Edition bilingue Aubier Flammarion. 